\title{
Mine Mining Problem In The Village Village (A Review of Ecotology On Gold Mining Practices By Villagers of Bawan Central Borneo)
}

\author{
Sarmauli, M.Th \\ Institut Agama Kristen Negeri (IAKN) Palangka Raya \\ uli_rahul2002@yahoo.com
}

\begin{abstract}
In ecology, humans are created to rule over nature. But dominating nature is not by dominating what is destructive. Based on this, the problem formulation of this research is How is the understanding and theological attitude of Bawan citizens towards ecological damage due to gold mining? How do you understand the anthropological analysis of gold mining in Bawan Village? The purpose of this study is to describe the understanding and attitudes of community members about environmental damage caused by gold mining in the village of Bawan. research uses qualitative methods because who wants to find answers to problems "by examining various social and individual settings that hinder these settings. The focus of this qualitative research is on the dimension of" unverifiable facts "regarding people. The conclusion is the lack of understanding of community members about environmental damage caused by gold mining.In solving the problem of gold mining in the village of Bawan must use specific analysis to include elements of adaptation in the analysis, ecological theory explains the systemic relationships and interdependence between components, this occurs because it includes elements of the physical environment and social environment Implications The consequence of the approach to the community as gold miners is the closer anthropological analysis to the practical problems faced in the community.
\end{abstract}

Key Words: Gold Mining, ecotological demage, Village of Bawan

\section{Introduction}

Humans and the environment are two things that can not be separated, humans need the environment to meet their needs. Most human activities involve the environment, both directly and indirectly. The relationship or interaction between humans and the environment, if done irresponsibly will disturb the balance and preservation of nature, disturbance of the balance and preservation of nature will have an impact on human life. Mining Business is part or all stages of activities in the framework of research, management and exploitation of minerals and coal which includes general investigations, exploration, feasibility studies, construction, processing and refining of mining, transportation and sales as well as post mining activities (Article 1 number 6 of Law no. 4 of 2009 concerning Mineral and Coal Mining). Mining can be grouped into two types, namely large scale mining (small scale mining) and small scale mining (small scale mining). Small scale mining or in other terms small scale mining is a mining business carried out by people and is often referred to as community mining.

Massive exploitation of natural resources on planet Earth began with forest encroachment, forest fires, and mining of agricultural products, such as mining diamonds, coal and gold. The environment is a unity of space with all objects, forces, conditions, and living things, including humans and their behavior, which affect the continuity of the welfare of humans and other living things. The environment damaged due to exploitation activities covers various 
fields, including damage to land, water, forests and biodiversity, energy and minerals, marine biological resources and so on [1].

U.S.Worldwacht Institute in 1984 reported a prediction about environmental damage. According to him, if we look at environmental pollution, then in 2000 there was one species missing every hour. Since 1950, we have lost $5 \%$ per year of land to grow crops and tropical forests to attract rain. Each year we lose 20-25 million tons of humus through erosion, salting and becoming deserts. Each year 20 billion hectares of forest is lost. Indonesia destroys forests approximately 51 square kilometers each day [2]. Environmental damage is one of them due to gold mining. Gold mining exacerbates the quality of natural resources and the environment that is not only detrimental to the present generation, but also bring harm to future generations. One example of environmental damage caused by gold mining occurred in Bawan, Banama Tingang District, Pulang Pisau District, Central Kalimantan Province. If the water is seen from above, it will appear the color of the water looks brownish, while many other areas, visible expanse of sand that is large enough, this sand expanse of gold mining activities, resulting in the uplift of sand material to the top resulting in siltation. J.E. Lovelock, in his book Gaia, A New Look at Life on Earth said that Borneo as a "living being" is being afflicted with illness [3].

U.S.Worldwacht Institute in 1984 reported predictions about environmental damage. According to him, if we pay attention to environmental pollution, then in 2000 there was one species that was lost every hour. Since 1950, we have lost $5 \%$ per year of land for agriculture and tropical forests to attract rain. Every year we lose 20-25 million tons of topsoil from erosion, salting and desert. Every year 20 billion hectares of forest are lost. Indonesia destroys forests around 51 square kilometers every day [4]. One of the environmental damage due to gold mining. Gold mining worsens the quality of natural resources and the environment which not only endangers the present generation, but also endangers future generations. One example of environmental damage due to gold mining occurred in Bawan, Banama Tingang Regency, Pulang Pisau Regency, Central Kalimantan Province. If the water is seen from above, you will see the color of the water looks brownish, while many other areas, a vast expanse of sand is visible, this expanse of sand is caused by gold mining activities, which results in the removal of material sand which causes siltation. J.E. Lovelock, in his book Gaia, A New Look at Life on Earth said that Borneo as a "living creature" who was stricken with disease [5].

Of the many mining activities in the world, whether managed by companies or managed by communities, all contribute to global climate change which not only threatens one particular area but the entire world. Environmental damage due to exploitation of nature is not only caused by the presence of large companies but because of the lack of awareness from the community, towards the preservation of nature and the environment in their area. This can be seen from the destruction of land and rivers due to unlicensed gold mining, in the village of Bawan which is part of the community's livelihood. Bawan Village is one of the villages in Banama Tingang District, Pulang Pisau Regency, Central Kalimantan. Bawan which used to be a plantation area with a stretch of rubber trees and community fields is now entered by gold processing suction machines and holes large enough in diameter at the bottom of the river, not only that, this gold mining activity also produces siltation in the river due to sand material and pebbles raised up to the surface from the riverbed resulting in the formation of a stretch of white sand, it can be seen clearly if the state of the river water is receding.

Mercury $(\mathrm{Hg})$ or mercury which is a chemical element in the form of liquid metal which is silver and poisonous is used by miners as a separator between gold or black fine sand or often called Puya [6]. From the process of separating gold from fine sand, this will produce mining waste that is harmful to the body, and also living things in the polluted area. Mercury waste, 
also known as one of the mining industry wastes that is deadly slowly when in direct contact with living things. The suction machines for gold processing have now operated on the banks of the river close to residential areas.

There have been many recent studies that have been carried out regarding land changes due to mining. One of them Wohlfart et al (2017) in his research, has succeeded in modeling the spatial damage of the environment due to small-scale gold mining in the area around the Sungai Kuning watershed. In addition, remote sensing imagery presents objective and detailed spatial notes on land use / land cover (LULC), and change detection methods can provide quantitative insights about regional land cover trends[7]. According to Redondo-Vega et al., (2017) mining activities occupy a relatively insignificant amount of land compared to other anthropogenic changes in all parts of the world, but these activities are quite disturbing and clearly visible. Recent studies of the effects of mining on land use change have been widely carried out in the world[8]. This research is almost everywhere in the world [9], including in Indonesia. In Indonesia several studies related to land use changes due to mining activities, namely in East Luwu [10], Bangka [11] and Belitung[12]. This research is almost the same as the study conducted by [13] about the spatial model of land damage and water pollution in the West Kalimantan Raya Watershed, but in this study vegetation indicators were included as indicators. Brata Research (2016) on the Dynamics of the Hargomulyo People's Oil Mining Organization Structure and the Social Economic Impacts of Surrounding Communities. Other researchers who are also researching mining are Kessey and friends (2013) studying environmental damage caused by small scale gold mining entitled Small Scale Gold Mining and Environmental Degradation, in Ghana: Issues of Mining Policy Implementation and Challenges. Brata (2007) also studies the development and economic movements by utilizing natural resources and the environment in mining areas in South Sumatra, entitled Talang, Hamlet, and Village in South Sumatra in Anthropological Ecological Analysis. Brata (2014) also studies the community oil mining in East Java, entitled Oil \& Community Welfare: A Case Study on People Oil Mining in Indonesia. Goswami (2013) examines the impact of coal mining in India, which has the title Susceptible Development: Impact of Coal Mining on the Environment in India.

\section{Research Method}

The problem formulation in this research is on the ecological problem caused by gold mining by Bawan villagers. Based on the above background, then the formulation of the problem as follows:

a) How is the theological understanding of the Bawan people against the ecological damage caused by gold mining?

b) How are the Bawan people's attitude towards the ecological damage caused by gold mining?

c) How to understand the ecological anthropological analysis of gold mining in Bawan Village?

\subsection{Research purposes}

Related to the problem and its scope in Tangkahen village, research aims to:

a) Describe the understanding of the people about the environmental damage of the environment due to gold mining in Bawan village. 
b) Describe the attitude of citizens to the environmental damage caused by gold mining in Bawan village.

c) Analyzing the ecological anthropology of gold mining in Bawan Village.

\subsection{Benefits of research}

a) Enterprises in developing and deepening science about environmental damage in Bawan village.

b) Providing thought contribution for Bawan villagers about the danger of environmental damage caused by gold mining in the village of Bawan.

c) The role of village leaders in providing direction and awareness for Bawan villagers.

\subsection{The Scope of Research}

This research is limited to the scope of its territory, namely in Bawan Village, Banama Tingang District, Pulang Pisau Regency, Central Kalimantan as a unit of research analysis, and data source for the interest of content analysis is the community in Bawan village. Field research was assisted by STAKN students in Palangka Raya, where researchers served as lecturers.

\subsection{Theoretical Framework}

Ecology comes from the Greek oikos Shelter (home) and logos (Science or knowledge). Both of these words form the notion of home, but this understanding then develops into an ecology that examines the relationship between different creatures and their relationship to the place where they live, with climate, types of plants and so on [14]. The term ecology was first introduced by Ernst Haeckel a zoologist in 1869 as the science of interaction between all living things and their environment. The issue of environmental insights at present develops a sense of responsibility towards the environment and encourages an ecological position in terms of academics to be a common concern [15]. Sedangka Odum (1993) states that ecology is a study of the structure and function of ecosystems or nature and humans as part of it. Ecosystem structure shows a state of the ecological system at a certain time and place including the state of the density of organisms, biomass, material distribution (nutrients), energy, and other physical and chemical factors that create the state of the system [16].

In accordance with modern scientific thought is that the ancient Greek philosophers recognized / knew that humans were influenced both by nature and by the power to change in their environment. There it is stated, for example, that various forms of political organization from city states in Greece and in the empire in the East reflect the influence of seasons on the personalities of their inhabitants. This theme was later developed by Montesquieu and the writers of the French Enlightenment / Enlightenment and in the latter days was used by American geographer Samuel Huntington. Other classical writers commented on the destruction of landscapes in Attica and North Africa caused by deforestation and overgrazing, a theme taken in the mid 1800s by George P. Marsh, whose book "Man and Nature" or Phisical Geography as Modified by Human Action "are the most popular writings that prove the existence of ecological destruction. These early writings, in general, are more anecdotes that do not present the theory of human relations and their environment coherently. Only at the end of the nineteenth century, with the development of geography and anthropology as scientific disciplines, human ecology became the subject of systematic study. The first 
theoretical approach to try is environmental determinism - a false start that greatly slows the development of human ecology that follows [17].

Planet Earth as a human home and all other physical objects, the environment is understood in the sense of oikos, because oikos of the earth has a very important function, namely as a place to live (oikoumena) and as a source of life (oikonomia). In general, ecology can be interpreted as the relationship between organisms and their habitats, or the study of the relationship between living things and their environment [18]. Until now planet earth was the only place that made life possible. Although humans continue to try to find and manipulate the lives of other diplanets, but humans have not found other alternatives to be able to live other than on planet Earth. That is why the planet must and must be maintained, because damage to the earth means a threat to human life itself [19].

In some traditional societies, the environment is not limited to land or dwellings. The environment is our life. The environment is the place of origin of a clan, where the lineage is located and formed, where the ancestral graves are located, the shrines for prayer and other shrines associated with the cosmos of traditional societies. culture and the environment are important components of life, and support each other. Someone determines one's behavior, and vice versa. Culture, in people's perception means preserving "the environment", and the environment will not exist if culture is also not respected. Both are interrelated and are the key to human survival.

One thing that should not be forgotten by humans, that nature and everything in it is increasingly reduced carrying capacity. Considering that the carrying capacity of nature is very important for human survival, the ability to use capacity of nature must be maintained so that it is not damaged and has a negative impact on humans. In general, natural damage can be divided into two factors namely; damage due to internal factors, which originate from within the earth / nature itself. For example: volcanic eruptions, earthquakes, sea waves, etc., and damage due to external factors is damage caused by human activities in order to improve the quality and comfort of life. External damage is usually caused by industrial activities, in the form of industrial waste, forest and land exploitation such as forest encroachment and gold $\operatorname{mining}[20]$.

The use of mercury in industries, especially in the mining industry, often leads to environmental pollution, either through waste water or through air ventilation systems. Mercury is wasted in the river, can contaminate fish and other aquatic creatures including algae and aquatic plants. Furthermore fish or other aquatic animals that have been contaminated with mercury are then consumed by humans so that humans can collect mercury in their bodies. FDA puts the limit on maximum mercury content of $0.005 \mathrm{ppm}$ for food, while WHO (World Health Organization) maximum limit is lower, is $0.0001 \mathrm{ppm}$ for water. Mercury poisoning is mainly by consumption of mercury-contaminated fish, or plants that are in direct contact with contaminated water. Although the mechanism of mercury poisoning in the body is not known clearly, but some things about the mercury toxicity in sufficient quantities of mercury components in the amounts are quite toxic to the body, mercury in the body suspected to inhibit the enzyme work is usually permanent and has not been able to recover .

Mining business carried out by the community in a small scale is also one of the causes of environmental damage and pollution. In gold mining in the process of mercury amalgamation $(\mathrm{Hg})$ is used as a medium for binding gold. Given the dangerous nature of mercury, the spread of this metal needs to be monitored so that prevention can be done as early as possible.

The impact of gold mining on the ecology where water is often polluted by various organic components, including by various types of dangerous heavy metals, some of which are widely 
used in the continuous mining industry. Hazardous heavy metals often pollute the environment, which are mainly mercury $(\mathrm{Hg})$, Lead $(\mathrm{Pb})$, Arsenic (As), Cadmium (Cd), Chromium (Cr), and Nickel (Ni). The metal is known to accumulate in the body of an organism and remain in the body for a long time as accumulated poisons. Mercury is written with the chemical symbol $\mathrm{Hg}$ or hydragyrum which means "liquid silver". Mercury is an element that often pollutes the environment. The chemical and physical properties of mercury make these metals widely used for industrial chemical purposes.

The use of mercury in industry, especially in the mining industry, often results in environmental pollution, both through wastewater and through air ventilation systems. Mercury which is wasted in the river, can contaminate fish and other aquatic creatures including algae and aquatic plants. Furthermore, fish or other aquatic animals that have been contaminated with mercury are then consumed by humans so that humans can collect mercury in their bodies. The FDA has set a maximum mercury content limit of $0.005 \mathrm{ppm}$ for food, while WHO (World Health Organization) has a lower maximum limit of 0,0001 ppm for water. Mercury poisoning is mainly caused by consumption of fish contaminated with mercury, or plants that come into direct contact with polluted water. Although the mechanism of mercury poisoning in the body is not yet clearly known, but a number of things regarding the mercury toxicity in an adequate amount of mercury component in sufficient quantities toxic to the body, the effect of mercury in the body is thought to be able to inhibit the work of enzymes that are usually permanent and to date have not been cured.

The impact of gold mining on health, because water that has been polluted by mercury waste can cause huge losses to humans, losses that are felt directly by humans, water cannot be used for household, agricultural and other industrial needs. Water that has been polluted by mercury waste is also a cause of disease, both infectious and non-communicable. Diseases that can be caused by water that has been polluted by mercury waste are, mercury poisoning, cancer, headaches and others [21].

The activity of polluting the environment carried out in certain places not only has a negative impact on the environment, but can also extend to other environments to aid water flow and wind gusts. For example, upstream industries that pollute the water environment will have a negative impact until it reaches the river, even to the sea. With the long-term and widespread nature of pollution in an unlimited environment, pollution can be considered as a very dangerous environmental destroyer. The current global environmental damage is very worrying, such as the problem of global warming and the occurrence of ozone holes, is the impact of pollution that is widespread and accumulates over a long period of time. This also proves that the problem of pollution is a problem that is very broad and complicated in scope.

Environmental pollution is usually considered a by-product of human activities in development, especially industrial development, agriculture, transportation and daily activities. this activity produces by-products called waste. Waste contains pollutants that are poisonous and dangerous. This waste is known as B3 waste (toxic and dangerous material). This material is formulated as a material that has the potential to pollute / damage the environment and natural resources. Waste from industrial, agricultural and mining activities in the form of gas and liquid and solid waste, is the main pollutant for the environment[22].

The ecoteological view of human ecological problems has very far interfered with and manipulated natural life into artificial natural life, it has resulted in the disruption of ecosystems on the earth, the term used by Christian theology regarding the environment or nature is 'creation'. The use of this term stems from the belief that the environment or nature was created by God and not something that happened by itself. 
Steward's concept of cultural ecology has proven to be a powerful and effective strategy of resetting human ecology, which offers a new understanding of how traditional societies adapt effectively to their environment. This success was achieved because it was mainly in smallscale studies, namely primitive societies, especially where stable relationships have formed between static populations and unchanging environments. This concept is less applicable to complex modern societies where the actions of the human population generally produce rapid environmental changes with the consequent need for cultural adaptation[23].

Anthropology Ecology has existed since 1960, some Anthropologists have talked about it such as Daryll Forde, Alfred Kroeber, and Julian Steward [24]. Some of the studies from anthropologists have inspired some anthropologists such as Roy Rapport and Andrew P. Vayda who are trying to develop the anthropological approach. Conrad P. Kottak divides ecological anthropology into two based on its development, namely the old ecological anthropology and the new ecological anthropology. The old ecological anthropological approach has shortcomings so that the emerging anthropological approach tries to fix the deficiencies of the old anthropological approach[25].

Based on an approach to the concept of an ecological system formulated by biological ecologists after World War II, American anthropologists Andrew Vayda and Roy Rappaport stated that in addition to studying how culture is adapted to the environment, attention must be focused on the relationship of certain human populations to certain ecosystems. In this view, humans are just another population among plant populations and animal species that interact with each other and also with the non-organic component of their local ecosystem. So ecosystems, not culture, are fundamental units of analysis within their conceptual framework on human ecology. Cultural characteristics are important insofar as they can be demonstrated to contribute to population survival in the context of ecosystems. Vayda and Rappaport reported in his book "Pigs for the Ancestors" explain this.

Anthropologists examine cultural habits and beliefs that enable humans to manage their environments so that humans can adapt and maintain existing ecosystems so they are not damaged. Differences between the new and old ecological anthropology involve policy and value orientation, application, unit of analysis, scale and method. Changes in approach in ecological anthropology are certainly influenced by the development of technology, information, culture of a community that is always developing, the development of ecosystems both from within and from outside parties, migration, tourism development and the use of some social, economic and political interests of several parties [26].

Furthermore adaptation, environment and culture are very important things for humans, and all three are interrelated to each other. Adaptation is an adaptation strategy that humans use throughout their lives to respond to the environmental changes they face. Through this adaptation, humans can survive in their environment with various challenges that exist in each environment. The challenges that are born by the environment (physical environment and social cultural environment) require humans to be able to live in harmony with their environment. Because by living in harmony with the environment man can maintain his life. If humans are unable to adapt to their environment, they will fail and be selected by their own environment. Therefore, environmental conditions greatly affect what adaptation strategies chosen by humans which will also give birth to different strategies in each community to respond to the challenges that exist in their environment. Adaptation by humans to the environment shows the relationship between humans and the environment. While its association with culture is that culture is an expression of human adaptation to environmental conditions. Differences in the environment of residence will affect the culture of each community, and cultural differences will affect the patterns of adaptation undertaken. So 
based on the explanation above, it can be seen the relationship between adaptation, environment and culture which are bound together with each other and are an inseparable part of human ecological reality. This shows the interrelated relationship between the physical environment and the socio-cultural system of the community.

This type of research is qualitative. Qualitative research is research that uses a case study format, this research also generally directly conducts data collection with participatory methods, such as in-depth interviews and participatory observation [27]. Basically research relies on empirical facts as analytical material to produce accurate conclusions on the phenomena under study [28] In other words qualitative research also seeks to understand and interpret the meaning of an interaction of human behavior in certain situations according to perspective the research itself [29].

Furthermore, research uses qualitative methods because it wants to find answers to problems "by examining various social settings and the individual who inhibits these settings [30]. The focus of this qualitative research is on the dimension of "unquantifiable facts" with regard to people. The process of implementation refers to the "spiral model of the research approach" [31], namely through a sequential path: from ideas, literature review, design, data collection, analysis and findings, until finally dissemination of research results.

This research also uses the Progressive (PC) Contextualization Method which is a research method developed by Andrew Peter Vayda in conducting anthropological or ecological human research. The advantage of doing a PC in ecological anthropological research as explained by Vayda is that researchers can conduct thought experiments in the context of actors. That is, researchers with their involvement in the context of actors (participatory observation) then researchers can develop new assumptions based on findings in the field. Thus basically the research conducted can be developed into several studies in accordance with the ability of researchers to develop new assumptions. With a PC, researchers can actually develop research questions according to the situation in the field. New assumptions made while in the field allow researchers to conduct research on an ongoing basis in new research themes. If the research is to be continued, then new assumptions must be developed, so that the research is carried out continuously / progressively [32].

Within this research framework, qualitative research becomes dominant with both qualitative and quantitative data. Within this qualitative research framework, many procedures need to be considered, and one important part is expanding qualitative research assumptions, including: 1) its primary concern in processes other than outcomes or products; 2) Value and meaning (how people rationalize their lives, experiences and world structure); 3) The writer becomes the main instrument; 4) includes fieldwork. The writer encounters people, settings, sites, or institutions to observe or record behavior in their natural setting; 5) Is descriptive in which the writer is considered into the process, meaning and understanding obtained through words or images; 6) The process is carried out inductively in which the researcher builds abstractions, concepts, hypotheses and theories from details [33].

\section{Result and Discussion}

\subsection{Theological Understanding of Residents Against Ecological Damage Due to Gold Mining}

From the interview with Priest I Nyoman S.Th concerning their theological understanding of the practice of mining of gold on the environment is as follows: 
"Gold mining is considered contradictory to the Bible during its work of parading to the exploitation of nature. That gold mining should be the survival of other living beings, because in the Bible we are being asked to rule and conquer it does not mean to destroy or destroy but to preserve, maintain and repair what is broken" (Interview with September 14, 2017).

From the above statement that the role as a human should not only pursue material gain but also must think about the survival of other living things. Humans have a big duty and responsibility that is to maintain each other, maintain and repair what has been damaged, in other words re-greening. Thus gold miners are responsible for the survival of other creations according to the Word of God. Gold miners should not only be able to pick up the results of nature but how to practice in accounting for the consequences of gold mining. Some gold miners are being asked about their theological understanding of the gold mining practices of the environment. According to Mr. Tuteng's statement as follows: "According to my understanding the practice of gold mining does not violate or challenge the Bible because it only takes the results that God has provided" (Interview with September 15, 2018).

From interviews with gold miners on their theological understanding of the gold mining practices to their environment, what they are doing is a natural thing to do. Gold mining is the livelihood of most people, people still depend a lot of their income from the gold mining business. Because for them the proceeds from gold mining can meet the needs of everyday life, compared with rubber tapping that depends on the weather conditions.

The facts that exist in the field based on the results of research due to economic reasons, and the absence of jobs that can ensure the fulfillment of daily needs, and for that reason they ignore what has been written in the Bible. Citizens who work as gold miners claim that the scriptures have written human domination over nature and set an anthropocentric tendency. Because of the mistake of thinking that makes them look at nature only from the human point of view. This means that the center of this world is human and therefore the creation of another must serve man. The value of other creations depends on usability and benefit for human and human communities. From here born arbitrary action or exploitatip action of man against nature.

\subsection{Attitudes Bawan residents against Ecological Damage Due to Gold Mining}

Speaking of the attitude of Bawan residents to the ecological damage caused by the gold mining of Pdt. Priest I Nyoman S.Th states:

"The miners should not be too pushy on what is there, such as sucking up the damaged lands and the river bank and the river become shallow, one of the best ways miners should do is if they damage the environment due to the entry of gold miner machines, they should think of other alternatives so that the environmental damage does not get worse "(Interview with September 29, 2017).

From the research results, the lack of cooperation and awareness of the residents against the environmental damage caused by gold mining resulted in them having an attitude that could be said to be indifferent, although in theory they know what should be done but there is no follow-up to do the practice in the field. 
To appreciate nature means to love God the Creator who has expressed His love for all creation. Appreciating nature means exercising God's love and acknowledging the dependence of all of God's creation. Environmental damage due to gold mining, Bawan residents who work as gold miners have traditional interpretations, they maintain the superiority of human beings over other creations because at the time of Allah's creation gave command to man and man has a special relationship with God. Man was created by God in the image and likeness of God so man acts as a "ruler" over other creations.

The ecological crisis is not because of the message of the Scriptures but because of a misinterpretation of the text of the Scriptures. Humans should no longer consider themselves to be God's representatives ruling over all other creations even though the image and image of God is inherent in human beings themselves. The granting of human dignity to humans at the time of creation is actually giving up responsibility to humans to regulate the world so that it runs well. Responsibility means that humans manage the universe (in this case the environment), because the universe has its own value that is within itself that must be respected by humans.

Humans do not arbitrarily act on the universe, but he must respect the innate values that exist in every creation. This concept implies that humans must treat the universe as a subject. The universe is worthy of respect. The universe has an intrinsic value that makes itself must be respected for its existence.

As God's creation is different from other creations, humans are determined to be masters of other people. Humans are given the power to cultivate the earth and its entire environment and to master it. "Power" is not a right or authority to destroy what is entrusted. Power is equated with the authority possessed by the "King", makakuasa is intended as a responsibility, to care for, protect, protect and bestow blessings. God ended the whole creation with the word really very good (Genesis 1:31) which revealed that all that was created was as God intended [34].

\subsection{Anthropological Analysis of Gold Mining Ecology \\ a. The reason for doing Gold Mining Practice}

From the interview with Priest I Nyoman S.Th regarding the reasons for the gold mining practice as follows: "The main reason to date is the gold mining practice is the absence of jobs that promise sufficient results to meet the needs of children's schools and daily needs" (Interview with 14 September 2017). In connection with the results of the interviews, the congregation members of gold cultivation communities, Mr. Tuteng and Mr. Otun stated that "the main reason to practice gold mining is to earn money to meet the needs of children's schools and daily needs" (Interview with 15-16 September 2017). The same thing in katakana bapak Puyuk and Kacul "the money can get from working as a gold miner to help meet the needs of the family and include college students." (Interview with 15-16 September 2017). Likewise, Mr. Pendi and Awung are "looking for money to buy food, and to finish building houses, and to fulfill the responsibilities to meet the needs of elderly parents (Interview with September 17, 2017). From the results of research in get that the reason the congregation members who do the gold mining practices are almost the same that is: the practice of gold mining due to economic factors as well as educational factors.

\section{b. Due to Gold Mining for Environment and Health}

When asked about the consequences of gold mining for the environment and health of Priest I Nyoman S.Th said "the practice of mining of gold destroys the environment, because 
the forests and the land run out as a place of mining, and river water is no longer feasible to be used because the exhaust of oil and mercury (mercury) is wasted into the river, health because it can be consumed by humans from fish or vegetables living in contaminated places "(Interview with 15-16 September 2017). The same question to Mr. Tuteng and Mr. Otun said "gold mining is destructive to the environment, the proof is that my rubber plantation is gone because it has been used as a suck lantern, and many piles of sand, fallen trees felled. Perhaps the waste from gold mining practices affects health because of the nausea and dizziness that is often felt when we bathe at work "(Interview with 15-16 September 2018).

Similarly, said the father Puyuk and father Kacul "gold mining can not be said as the only environment destroyer because the environment can be damaged also by itself like due to flood or angina fast. Gold mining waste is also perceived as affecting health because of frequent nausea and when we bathe at work site we get skin diseases and itching "(Interview with 17-19 September 2018).

From the results of the research found that gold mining has bad consequences for the health and also the environment, it is seen from the destruction of community plantations because in tebang for the place of mining and also the amount of sand due to siltation, other than that the water turns arna become turbid and fish -is not visible where the work location. In addition, the practice of gold mining is also bad for health, it is due to the frequent feeling of nausea, vomiting and dizziness that occurs in the workers, not only that workers often complain of skin diseases and itching if they use water around the mine.

Liquid waste or solid waste will increase if gold production increases. The drum machine is used as a material separator, uncontrolled waste disposal will have a negative impact on the miners themselves and the surrounding community. This waste will be increasingly discharged in water catchment areas such as soil. Because existing waste contains a lot of mercury, there must be direct control from the government so that the waste produced can be reduced and the mercury content of the waste can be reduced.

\section{c. Overcoming Gold Mining Practices Do not Destroy the Environment}

When asked how to overcome the gold mining practices do not damage the environment Priest I Nyoman S.Th, Mr. Tuteng and Mr. Otun said the same thing is "Better to take another alternative that is to return to the traditional way and not to force nature" (Interview with 14,15,16 September 2017). The same thing is said to be the father of Puyuk, the father of Kacul, the father of Pendi and the father of Awung "back to nature only, but if only so our results are not sufficient" (Interview with 19.22 September 2017).

From the results of the study found that the practice of gold mining can be done without destroying the environment by using the traditional way or back in the era where workers do not know the machines suction, they know only dulang (separator between gold and sand) made of ironwood which is in the form of a phonograph record. Workers take only sand on the banks of the river and sprinkle a little detergent as pelican so that the sand can quickly separate from gold, but according to them the results are not sufficient to meet the daily needs of the growing.

\section{d. Ecological Anthropology Approach with Progressive Contextualization Method}

Bawan Village, Banama Tingang Subdistrict, Pulang Pisau District, Central Kalimantan is the right object to study or analyze with the perspective of ecological anthropology and theology as well as there are ecological phenomena and interactions with human behavior. The problems that occur as a result of the many illegal gold mines today are the activities 
carried out by the community and various companies as a form of strategy in exploiting, utilizing and preserving the environment and culture. Environmental problems and the impact of development create various paradigms to study human and environmental interactions. As Steward expressed about how the interaction between culture and environment can be analyzed in a causal framework without having to slip into particularism. Three basic steps in the study of cultural ecology that according to Steward need to be followed: 1) Conduct an analysis of the relationship between the environment and technology utilization. 2) Conduct an analysis of behavioral patterns in the utilization of a certain area using certain technologies. 3) Conduct an analysis of the level of influence of behavioral patterns in the use of the environment on other aspects of culture.

Analysis of the relationship between humans and their environment has also been written by Rappaport and Vayda in their studies in various regions including Indonesia. They use the term human ecology which focuses on various relationships between humans and their environment. In contrast, Steward and Geertz took a large locus of society and used a comparative method. Rapaport and Vayda emphasize their studies on small communities that are explored more broadly and in depth about the various environments between humans and their environment and their relationship with the ecological balance in a particular community. Vayda and Rappaort (1968) co-wrote Ecology, Cultural and Non Ecology; Introduction to Cultural Anthroplogy which explains the relationship between population development and issues of ecological balance in a more complex way.

Based on Vadya's research on ecological anthropology and the method of progressive contextualization, the most important thing is that researchers must be able to uncover 'external factors' and 'internal factors' whose purpose is holistic research results by looking at all aspects of community life under study with problems environment that happens. A note for researchers who use this method in ecological anthropological research is not to ask "should" but rather to ask "why". The aim is to express the deepest problems that occur in the environment under study. Also do this research on an ongoing basis so that this research can reveal the external factors and internal factors behind the problem under study [35].

By incorporating elements of adaptation in its analysis, ecological theory explains the systemic relationships and interdependencies between components, paying attention to the process of developing, maintaining and changing relationships between components. Ecological analysis can work like that because it incorporates elements of the physical environment and social environment. Thus ecological analysis can explain empirically why and how / the process of environmental change occurs [36]. The approach leads to the concentration of discoveries who do what, why they do it, and how their effects are highly concentrated on findings that can be directly used by decision makers[37]. In doing so we can start with the actions or interactions of individual lives and can be directed to contexts that make actions or interactions understandable by showing their location in the complexity of cause and effect relationships. There is no a priori assumption that needs to be made. However, regarding complex permanence with units defined / or previously identified for the purpose of system analysis. So progressive contextualization helps us by taking a holistic understanding without the help of the system framework and the right assumptions about system stability and about the mechanism of how stability occurs [38].

In solving the problem of gold mining in the village of Bawan it should be done by using site-specific analysis and recommendations on approaches that emphasize the environment and do not sacrifice culture and society. Keep in mind the superiority of society and culture in their analysis and not just focus on ecological data. Sources of funding that give priority to science, finance expensive equipment and support advanced technology must not keep us from 
focusing on cultural specificity and social and cultural variables. The contribution of the government is to promote the people rather than the good name. It must be seen that the issue of gold mining in Kalimantan is a matter of the struggle for life and there are no other alternatives for living. Very far from environmental awareness especially in the process of transcendence concerning the relationship of religion and the environment. In this case the government must actually be firm there are miners with large scale that can damage the environment.

\section{Conclusion}

Based on the findings, conclusions were obtained as follows:

a) Understanding the congregation of gold miners considers that the practice of gold mining is not challenging with the Bible, because their understanding is that human beings are given the right to use and take the produce of the earth that God has provided for human beings regardless of the survival of the existing ecosystem so that the citizens of this congregation more atopocentric.

b) Bawan villagers who practice gold mining realize that what they are doing destroys the environment, but they take it as a natural thing, so they do not care about replanting the damaged forest.

c) In solving the problem of gold mining in the village of Bawan it should be done by using site-specific analysis and recommendations on approaches that emphasize the environment and do not sacrifice culture and society. By incorporating elements of adaptation in its analysis, ecological theory explains the systemic relationships and interdependencies between components, paying attention to the process of developing, maintaining and changing relationships between components. This happens because it includes elements of the physical environment and social environment.

Based on the conclusions obtained several implications put forward as follows:

a) The consequence of the approach to the community as a gold miner is the approach of anthropological analysis to the practical problems faced in society, the approach to individual actors by departing from the question "Why" with contextualization that continuously enables ecological analysis to be integrated with analyzes of other disciplines to be able to express and overcome problems that arise in the process of environmental management. Such an approach can be easily used for decision making in overcoming imbalance relationships between units in the ecosystem, which is a starting point for the emergence of awareness of environmental preservation and understanding in the Christian faith.

b) Scientifically the research conducted is indeed to produce new concepts, theories and research methods. This means that research carried out for the benefit of the development of science, but the excavation of socio-cultural values that have the impact of conservation or protection of the environment and especially if it can spread it to other communities, of course will increase conservation of the environment will be even better. This is the practical benefit of a study, which is on the applied side of a science. Therefore, ecological anthropological research has 
opportunities for scientific development and also has applicative benefits for environmental improvement.

\section{References}

[1] Borrong, R.P. (2009). Etika Bumi Baru.Jakarta: BPK Gunung Mulia, 49

[2] Mali, Mateus, 2008, Ekologi dan Moral Dalam Menyapa Bumi Menyembah Hyang Ilahi. Yogyakarta : Kanisius, 139

[3] Alikodra, Hadi. (2008). Global Warming. Bandung: Nuansa. 157

[4] Mali, Mateus. (2008). Ekologi dan Moral Dalam Menyapa Bumi Menyembah Hyang Ilahi. Yogyakarta: Kanisius. 139

[5] Alikodra, Hadi. (2008). Global Warming. Bandung: Nuansa, 157

[6] Tim Redaksi Buku SMU. (2005). Mengenal Unsur-Unsur Kimia. Jakarta: Poliyama Widya Pustaka, 159

[7] DeWitt, J. D., Chirico, P. G., Bergstresser, S. E., \& Warner, T. A. (2017). Multi-scale 46-year remote sensing change detection of diamond mining and land cover in a conflict and post-conflict setting. Remote Sensing Applications: Society and Environment, 8(July), 126-139. https://doi.org/10.1016/j.rsase.2017.08.002

[8] Wu, W., Yao, J., \& Kang, T. (2008). Study on land use changes of the coal mining area based on TM image. Journal of Coal Science and Engineering (China), 14(2), 287-290. https://doi.org/10.1007/s12404-008-0062-9.

[9] Redondo-Vega, J. M., Gómez-Villar, A., Santos-González, J., González-Gutiérrez, R. B., \& Álvarez-Martínez, J. (2017). Changes in land use due to mining in the northwestern mountains of Spain during the previous 50 years. Catena, 149, 844-856. https://doi.org/10.1016/j.catena.2016.03.017.

[10] Hidayat, W., Rustiadi, E., \& Kartodihardjo, H. (2015). Dampak Pertambangan Terhadap Perubahan Penggunaan Lahan dan Kesesuaian Peruntukan Ruang (Studi Kasus Kabupaten Luwu Timur, Provinsi Sulawesi Selatan). Jurnal Perencanaan Wilayah Dan Kota, 26(2), 130-146. https://doi.org/10.5614/jpwk.2015.26.2.5.

[11] Yunito, M. R. (2016). Kajian Perubahan Penggunaan Lahan Akibat Penambangan Timah Berdasarkan Analisis Neraca Sumberdaya Lahan Spasial di Kabupaten Bangka. Jurnal Bumi Indonesia, 5(1).

[12] Pirwanda, F., \& Pirngadie, B. H. (2015). Dampak Kegiatan Tambang Timah Inkonvensional Terhadap Perubahan Guna Lahan di Kabupaten Belitung. Jurnal Planologi Unpas, 2(3), 177-194.

[13] Romiyanto, Barus, B., \& Sudadi, U. (2015). Model Spasial Kerusakan Lahan dan Pencemaran Air Akibat Kegiatan Pertambangan Emas Tanpa Izin di Daerah Aliran Sungai Raya, Kalimantan Barat. Jurnal Tanah Lingkungan, 17(2), 47-53.

[14] Mali, Mateus. (2008). Ekologi dan Moral Dalam Menyapa Bumi Menyembah Hyang Ilahi. Yogyakarta: Kanisius, 137-139

[15] Frick, Heinz., Suskiyantono, Bambang FX. (2007). Dasar-dasar Arsitektur Ekologis. Yogyakarta : Kanisius (Heinz Frick and FX Bambang Suskiyantono, 2007: 1)

[16] Oksfriani, Ekologi dan Antropologi Manusia http://oksfriani82.blogspot.com/2012/10/ekologi-dan-antropologi-manusia.html di unduh pada tanggal 12 Nopember 2019. 
[17] Muh. Sholeh. (2011), Pendekatan Konseptual Ekologi Manusia http://muhsholeh.blogspot.com/2011/04/pendekatan-konseptual-ekologi-manusia.html di unduh pada tanggal 01 Desember 2019.

[18] Wardhana, Wisnu Arya. (2001). Dampak Pencemaran Lingkungan. Yogyakarta: Andi, 10

[19] Borrong, R.P. (2009). Etika Bumi Baru.Jakarta : BPK Gunung Mulia, 18

[20] Wardhana, Wisnu Arya. (2001). Dampak Pencemaran Lingkungan Yogyakarta: Andi, $15-16$

[21] Wardhana, Wisnu Arya. (2001). Dampak Pencemaran Lingkungan Yogyakarta ; Andi, 133-134.

[22] Borrong, R.P. (2009). Etika Bumi Baru.Jakarta: BPK Gunung Mulia. 80, 84

[23] Muh. Sholeh (2011), Pendekatan Konseptual Ekologi Manusia http://muhsholeh.blogspot.com/2011/04/pendekatan-konseptual-ekologi-manusia.html di unduh pada tanggal 01 Desember 2019.

[24] Kotakk, C.P. (1999). “The New Ecological Anthropology,” American Anthropologist 101 (1): 23-35, 1

[25] Diah Puspitarini (2013), Review The New Ecological Anthropology Conrad P. Kottak http://diahpuspitarinii.blogspot.com/2013/10/review-new-ecological-anthropology.html di unduh pada tanggal 01 Desember 2019.

[26] Diah Puspitarini (2013), Review The New Ecological Anthropology Conrad P. Kottak http://diahpuspitarinii.blogspot.com/2013/10/review-new-ecological-anthropology.html di unduh pada tanggal 01 Desember 2019.

[27] Bungin, Burhan. (2001). Metodologi Penelitian Sosial. Surabaya: Airlangga University Press, 168.

[28] Anggoro, M.T. (2007). Metode Penelitian.Jakarta : Universitas Terbuka, 127

[29] Usman, Husaini., Akbar, P.S. (1996). Metodologi Penelitian Sosial, Jakarta : Bumi Aksara, 81

[30] Berg, Bruce L. (2007). Qualitative Research Methods for the Social Science. Boston: Pearson Education, 8.

[31] Berg, Bruce L. (2007). Qualitative Research Methods for the Social Science. Boston: Pearson Education, 24.

[32] Febrianto, Adri. Antropologi Ekologi: Manusia Dan Lingkungan Alam Fisik, Bahan Ajar Antopologi Ekologi, 44-45. https://docplayer.info/59561378-Bahan-ajar-hand-outmahasiswa-dapat-menjelaskan-studi-antropologi-ekologi-materi-antropologi-ekologimanusia-dan-lingkungan-alam-fisik.html.

[33] Cresswell, John W. (1994). Research Design: Qualitative and Quantittive Approaches, Thousand Oaks: SAGE Publication. 145.

[34] Henrika, M.Sr. (2008). Panggilan Berhati Ibu Bagi Semua: Kajian Ekofeminis Dalam Menyapa Bumi Menyembah Hyang Ilahi. Yogyakarta: Kanisius, 131.

[35] Vayda, Andrew Peter. (1983). "Progressive Contextualization: Methods for Research in Human Ecology", dalam Human Ecology. Department of Human Ecology, Cook College, Rutgers Univ, New York. Vol. 11, No.3.

[36] _ (1996). Methods and Explanations in The Study of Human Actions and Their Environmental Effects. ClFOR. Bogor.

[37] Vayda, Andrew Peter. (1983). "Progressive Contextualization: Methods for Research in Human Ecology", dalam Human Ecology. Department of Human Ecology, Cook College, Rutgers Univ, New York. Vol. 11, No. 3, 276. 
[38] Vayda, Andrew Peter. (1983). "Progressive Contextualization: Methods for Research in Human Ecology", dalam Human Ecology. Department of Human Ecology, Cook College, Rutgers Univ, New York. Vol. 11, No.3, 270-271. 